\title{
Psychologiczne i neuropsychologiczne aspekty podejmowania decyzji przez sędziów
}

1. Celem opracowania jest zwrócenie uwagi na zależności między cechami osobowości, temperamentu, stylu poznawczego ${ }^{1}$ sędziów a sposobem, w jaki podejmują decyzje w codziennej pracy. Podejmowanie decyzji jest bowiem ważne nie tylko z punktu widzenia codziennej aktywności każdego człowieka, umożliwiając adaptację do zmieniających się warunków otoczenia, lecz także z punktu widzenia pełnionej przez jednostkę roli zawodowej.

Autorki stawiają pytania, które uznają za ważne dla pełniejszego poznania i prześledzenia procesu decyzyjnego sędziego. Sygnalizują potrzebę i zamiar przeprowadzenia stosownych badań, które pozwolą na zweryfikowanie wiedzy, często intuicyjnej, na temat ,indywidualnego charakteru” sądowego stosowania prawa.

W przypadku sędziów poznanie tego procesu jest istotne, albowiem wydawanie decyzji jest ważnym i podstawowym zadaniem pełnionego przez sędziów urzędu. Sąd, jako ostateczny arbiter związany proceduralnym nakazem wydania decyzji, musi rozstrzygnać spór, a wydane orzeczenie rodzi często daleko idące skutki społeczne i prawne.

Tymczasem brakuje badań dotyczących psychologicznych aspektów funkcjonowania osób wykonujących zawody prawnicze w ich środowisku pracy, a w szczególności ich stylu decyzyjnego ${ }^{2}$, czynników, które wpływają na podejmowanie decyzji, metod radzenia sobie ze stresem czy zagrożeń związanych $\mathrm{z}$ wypaleniem zawodowym.

2. Tradycyjnym obszarem współpracy psychologów i prawników jest opiniowanie sądowo-psychologiczne. Przedmiotem zainteresowania psychologa sądowego lub biegłego sądowego z zakresu psychologii jest człowiek

1 Styl poznawczy to pojęcie odnoszące się do stałych wymiarów psychiki, odpowiadające różnicom indywidualnym w procesach spostrzegania, myślenia, zapamiętywania, uczenia się, organizowania i przetwarzania informacji. Zob. Cz. Nosal, Psychologiczne modele umystu, Warszawa 1999.

2 Przez styl decyzyjny rozumiemy sposób podejmowania decyzji, charakterystyczny $\mathrm{i}$ indywidualny dla danej osoby, niezmienny w czasie. 
uczestniczący $\mathrm{w}$ procedurach prawnych $\mathrm{w}$ fazie postępowania przygotowawczego lub sądowego - jako podejrzany lub oskarżony o czyn karalny, ofiara przestępstwa lub świadek zdarzeń stanowiących przedmiot sprawy. Ocenie podlega głównie stan psychiczny podejrzanych, oskarżonych i świadków oraz różne aspekty ich psychologicznego funkcjonowania. Zbieraniem, badaniem i przedstawianiem dowodów dla celów sądowych zajmuje się psychologia sądowa, będąca subdyscypliną psychologii stosowanej ${ }^{3}$. Literatura dotycząca tych zagadnień jest obszerna ${ }^{4}$.

Innym ważnym obszarem współpracy jest psychologiczna ocena kandydatów na urząd sędziego. Celem badań psychologicznych jest opis cech osobowości kandydata, jego umiejętność oceny sytuacji, zdolność do samodzielnego podejmowania decyzji ${ }^{5}$ oraz odporność na sytuacje stresowe ${ }^{6}$. Ocenie podlega zatem funkcjonowanie osobowościowe i poznawcze kandydatów na sędziów.

Badanie to ma jednak miejsce tylko raz, przed objęciem urzędu po raz pierwszy. Brakuje badań cyklicznych, sprawdzających, czy decyzyjna zdolność sędziego trwa czy zmienia się, a jeśli tak, to w jakim kierunku. Interesujące może być ujęcie zjawiska orzekania sędziego w perspektywie rozwoju jego osoby oraz w procesie dojrzewania zawodowego ${ }^{7}$.

3 A. Budzyńska, Psycholog w roli biegłego sqdowego, „Dziecko Krzywdzone” 2007, nr 4 (21): Teoria. Badania. Praktyka, s. 6.

4 Zob. np.: J. M. Stanik (red.), Wybrane obszary praktyki biegłego sqdowego psychologa, Katowice 1997; J. K. Gierowski, L. K. Paprzycki (red.), Niepoczytalność i psychiatryczne środki zabezpieczajace: zagadnienia prawno-materialne, procesowe, psychiatryczne i psychologiczne, Warszawa 2013; E. Gruza, Psychologia sqdowa dla prawników, Warszawa 2012; J. M. Stanik (red.), Psychologiczne i interdyscyplinarne problemy $w$ opiniodawstwie sqdowym $w$ sprawach cywilnych, Katowice 2011; B. Gulia, I. Niewiadomska, M. Wysocka-Pleczyk (red.), Biate plamy w psychologii sqdowej, Kraków 2010; M. Szostak (red.), Wybrane problemy psychologii sqdowej, Wrocław 2009; D. Hajdukiewicz, Podstawy prawne opiniowania sqdowo-psychiatrycznego w postępowaniu karnym, w sprawach o wykroczenia oraz $w$ sprawach nieletnich, Warszawa 2007; A. Lipczyński, Psychologia sqdowa, Warszawa 2007; M. J. Ackerman (red.), Podstawy psychologii sqdowej, Gdańsk 2005; M. Ciosek, Psychologia sqdowa i penitencjarna, Warszawa 2003.

5 Mamy tu na myśli tzw. decyzję sądową (decyzję finalną i decyzje cząstkowe: walidacyjną, interpretacyjną, dowodową i decyzję wyboru konsekwencji), którą rozumiemy w szerokim sensie teoretycznym, określonym przez pojęcie sądowego stosowania prawa-zob. J. Wróblewski, Sądowe stosowanie prawa, Warszawa 1988, s. 18.

${ }^{6}$ Zob. $§ 3$ rozporządzenia Ministra Sprawiedliwości z 8 marca 2002 r. w sprawie badań lekarskich i psychologicznych kandydatów do objęcia urzędu sędziego, Dz. U. 2002, nr 26, poz. 263: „1. Badania psychologiczne kandydata obejmują określenie i opis cech osobowości, z uwzględnieniem zdolności do podejmowania decyzji, zdolności do samodzielnego oceniania sytuacji oraz odporności na trudne sytuacje. 2. Zakres badań psychologicznych może zostać rozszerzony, jeżeli psycholog uprawniony uzna to za niezbędne do prawidłowego określenia sprawności psychologicznej kandydata".

7 Zob. np. uwagi M. Stępnia, Droga przemiany ,duszy sędziowskiej”. Ku aretycznej koncepcji orzekania sqdowego?, [w:] W. Staśkiewicz, T. Stawecki, Dyskrecjonalność w prawie, Warszawa 2010, s. 275-289. 
3. Na gruncie psychologii zagadnieniami podejmowania decyzji zajmuje się psychologia poznawcza, analizująca przebieg procesów decyzyjnych; psychologia społeczna, badająca wpływ grupy na sposób podejmowania decyzji i ich jakość, a w ostatnich latach także neuropsychologia i neurobiologia ${ }^{8}$.

Decyzja, ujmowana jako wybór jednej spośród co najmniej dwóch albo jednej z wielu możliwości, może też być wyborem alternatywnym, polegającym na wyborze wariantu $A$, jeśli będą spełnione warunki $X$, a wariantu $B$, jeśli zaistnieją warunki $Y$.

Podjęcie decyzji wymaga jednak na ogół dłuższego łańcucha złożonych procesów poznawczych, czyli myślenia i rozumowania wspomaganych działaniem uwagi, pamięci operacyjnej oraz pamięci trwałej. Procesy te, nazywane czynnościami decyzyjnymi, podporządkowane są określonemu celowi, czyli możliwemu do podjęcia wyborowi 9 .

Na przebieg procesu decyzyjnego wpływają takie czynniki, jak: indywidualne predyspozycje i doświadczenie jednostki, możliwości percepcyjne i zdolność oceny sytuacji, ważność celu, a także umiejętność kontrolowania emocji ${ }^{10}$. Istnieje też potwierdzone badaniami duże prawdopodobieństwo ulegania wpływom zniekształceń poznawczych, posiadanych przekonań, emocji, otoczenia społecznego, a wreszcie syndromowi grupowego myślenia w czasie procesu oceniania ${ }^{11}$.

Powstało wiele koncepcji dotyczących przebiegu procesu decyzyjnego: od klasycznych, które zakładają istnienie doskonale racjonalnego decydenta znającego możliwe opcje działania i wiedzącego, z jakim prawdopodobieństwem wystąpią możliwe konsekwencje wyboru poszczególnych opcji, wybierającego to, co zagwarantuje maksymalny zysk - po te, które uwzględniają złożoność sytuacji decyzyjnej oraz obecność takich czynników, jak dynamicznie zmieniające się otoczenie i ograniczenia ludzkiej percepcji ${ }^{12}$.

Czynności decyzyjne dokonują się w trzech fazach. W fazie przeddecyzyjnej decydent definiuje problem i zbiera informacje niezbędne do podjęcia decyzji. Informacje te obejmują dane na temat możliwych działań i ich wyników, a także informacje o stanach rzeczy i ich prawdopodobieństwie ${ }^{13}$. Im bardziej złożony problem decyzyjny, tym więcej informacji zbieramy na jego temat $\mathrm{z}$ otoczenia,

8 Neurobiologia - termin oznaczający różne dziedziny nauki badające układ nerwowy, których celem jest zrozumienie biologicznych podstaw świadomości i procesów psychicznych.

9 Zob. A. Falkowski, T. Maruszewski, E. Nęcka, [w:] J. Strelau, D. Doliński (red.), Psychologia, t. I, Gdańsk 2008, s. 480.

${ }^{10}$ Ł. Szczupacki, N. Falkowska, M. Jaracz, S. Augustyn, A. Borkowska, Temperament afektywny, funkcje czolowe i styl decyzyjny u osób zdrowych, „Psychiatria” 2010, t. 2, s. 47.

${ }^{11}$ Zob. T. Tyszka, Psychologiczne pułapki oceniania i podejmowania decyzji, Gdańsk 1999, s. $28-30$.

${ }^{12}$ M. Jaracz, A. Borkowska, Podejmowanie decyzji w świetle badań neurobiologicznych i teorii psychologicznych, „Psychiatria” 2010, t. 7, nr 2, s. 68-69.

${ }^{13}$ Zob. J. Kozielecki, Psychologia procesów decyzyjnych, Warszawa 1969, s. 23-24. 
dostępnych źródeł oraz zasobów własnej pamięci semantycznej ${ }^{14}$ i epizodycznej ${ }^{15}$. Konieczność zgromadzenia dużej ilości informacji wymaga współpracy wielu osób, a decyzje - często wypracowywane przez zespoły ludzi - wspomagane są bazami danych i różnymi środkami technicznymi. Ilość informacji zbieranych przez decydentów w tej fazie zależy od poziomu ich kompetencji. Najwięcej informacji zbierają zwykle decydenci średnio kompetentni; niekompetentni gromadzą ich mało, ponieważ nie wiedzą, gdzie szukać, nie są też w stanie ocenić, która informacja jest bardziej istotna, a która mniej. Decydenci o wysokim poziomie kompetencji wiedzą wystarczająco dużo, aby móc ograniczyć się do niezbędnych danych lub do sprawdzenia tego, o czym już wcześniej się dowiedzieli.

Kolejna faza podejmowania decyzji, określana jako właściwy proces podejmowania decyzji, polega na wyborze jednej możliwości spośród tych, które wcześniej zdefiniowano jako dostępne. Wybór polega na stopniowym wyróżnianiu jednej możliwości spośród pozostałych, a wybrana możliwość uzyskuje coraz lepsze logiczne i faktyczne uzasadnienie. W tej fazie procesu decyzyjnego ma też miejsce ocena ważności zebranych wcześniej informacji na temat dostępnych możliwości. Zależy ona od sprawności procesów poznawczych jednostki, czyli zdolności przywoływania wiedzy z pamięci trwałej, umiejętności sprawnego myślenia i rozumowania, a także doświadczenia decydenta oraz kontekstu podejmowania decyzji.

Ostatnia, trzecia faza podejmowania decyzji, obejmuje procesy postdecyzyjne. Typowe dla tej fazy są wątpliwości co do słuszności podjętej decyzji, tego, czy dokonany wybór był najlepszy z możliwych, a przynajmmniej dość dobry. Następują tu też próby zredukowania dysonansu poznawczego, czyli rozbieżności między spostrzeganą atrakcyjnością wybranej możliwości a celem, do którego decydent dążył.

Ponadto, procesy decyzyjne zależą od pracy poszczególnych struktur mózgu, których aktywność coraz lepiej udaje się poznać dzięki badaniom neuropsychologicznym oraz monitorować za pomocą metod neuroobrazowania, takich jak funkcjonalny rezonans magnetyczny.

W czasie podejmowania decyzji istotną rolę odgrywają przede wszystkim płaty czołowe mózgu. I tak, kora grzbietowo-boczna płatów czołowych odpowiada za utworzenie intelektualnej reprezentacji sytuacji i problemu decyzyjnego oraz analizę sytuacji problemowej, umożliwia planowanie i poznawczą kontrolę zachowania, bierze udział w uczeniu się zasad podejmowania trafnych decyzji i generalizowaniu uzyskanej wiedzy na inne sytuacje decyzyjne na podstawie zdobytego doświadczenia. Kora okołooczodołowa uczestniczy w adaptacji do dynamicznie zmieniających się warunków otoczenia poprzez monitorowanie skutków podejmowanych decyzji

${ }^{14}$ System pamięci trwałej, obejmujący m.in. zgromadzoną wiedzę.

${ }^{15}$ System pamięci trwałej, obejmujący pamięć zdarzeń wraz z ich kontekstem czasowo-przestrzennym, przechowujący ślady pamięciowe na temat zdarzeń oraz wzajemnych relacji między nimi, inaczej: pamięć autobiograficzna. 
i modyfikowanie decyzji adekwatnie do emocjonalnej wartości przypisywanej poszczególnym opcjom wyboru. Przednia część zakrętu obręczy odgrywa istotną rolę w podejmowaniu decyzji w warunkach niepewności, tj. ograniczonej dostępności wiedzy dotyczącej wartości i konsekwencji wyboru poszczególnych opcji; aktywizuje się w trakcie obserwacji i zbierania informacji o zachowaniu innych ludzi, a tym samym bierze udział w podejmowaniu decyzji w sytuacji wymiany społecznej ${ }^{16}$.

4. Sędzia podejmuje decyzje w określonej sytuacji decyzyjnej, w obrębie problemu faktycznego i prawnego, a na proces decyzyjny oddziałuje szereg determinant, np. czynniki natury podmiotowej, przedmiotowej i funkcjonalnej.

Proces podejmowania decyzji prawnej - choć w dużym stopniu sformalizowany, gdyż sędzia ma działać w granicach i na podstawie prawa - nie jest jedynie sądem logicznym, będącym wynikiem sylogizmu. Sędzia nie stosuje bowiem norm automatycznie, nie jest jedynie „ustami ustawy”.

W celu wydania decyzji, która ma być nie tylko praworządna i racjonalna, lecz także sprawiedliwa, sędzia przyjmuje postawę oceniającą, wartościuje. Bardzo często nawet w „pozornie najprostszych przypadkach” sędzia nie uniknie stawiania moralnych pytań. Dlatego też proces decyzyjny nie jest jedynie aktem wiedzy podmiotu orzekającego, ale i aktem jego woli ${ }^{17}$.

Jest to szczególnie widoczne w procesie sądowego stosowania prawa, kiedy wydanie przez sąd decyzji finalnej jest wieloetapowym procesem psychicznym i logicznym ${ }^{18}$, poprzedzonym koniecznością podjęcia decyzji cząstkowych. Dokonujący osądu podmiot decyzyjny - sędzia - posiada określoną osobowość, kształtowaną m.in. przez inteligencję, doświadczenie, emocje, wyobrażenia, dążenia, sumienie, przyjęty system wartości, które nadają podejmowanej decyzji wymiar osobowy ${ }^{19}$. Aksjologia sędziowska ${ }^{20}$ jest szczególnie widoczna w sferze dyskrecjonalnej władzy sędziego, kiedy sędzia może, a czasami powinien odwołać się do swobodnego uznania ${ }^{21}$ tam, gdzie sędzia poszukuje

${ }^{16}$ M. Jaracz, A. Borkowska, op. cit., s. 69-72.

${ }^{17}$ Por. M. Zdyb, Istota decyzji, Lublin 1993, s. 20-22. Zob. też uwagi E. Gapskiej w rozdz. I: Znaczenie sqdowych aktów decyzyjnych w postępowaniu decyzyjnym, [w:] E. Gapska, Czynności decyzyjne sqdów w postępowaniu cywilnym, Warszawa 2010.

${ }^{18} \mathrm{Na}$ temat normatywnych uwarunkowań sędziowskiego procesu decyzyjnego zob. M. Zubik, M. Wiącek, Kompetencje squdu konstytucyjnego a granice swobody orzekania, „Przegląd Sejmowy" 2009, nr 4, s. 26-29.

${ }^{19} \mathrm{Na}$ znaczenie walorów osobistych sędziego przy podejmowaniu decyzji zwracali już uwagę m.in. T. Romer, Etyka sędziego, [w:] E. Łojko (red.), Etyka prawnika. Etyka nauczyciela zawodu prawniczego, Warszawa 2002, s. 28; M. Safjan, Etyka zawodu sędziowskiego, [w:] E. Łojko (red.), Etyka prawnika..., s. 34.

${ }^{20} \mathrm{~K}$. Piasecki używa określenia „aksjologia podmiotowa niezawisłości sędziowskiej” - zob. K. Piasecki, Organizacja wymiaru sprawiedliwości w Polsce, Warszawa 1995, s. 116-119.

${ }^{21}$ Założenie, że dyskrecjonalna władza sędziego jest sferą swobodnej decyzji przyjmujemy za M. Pieniążkiem, Dyskrecjonalna władza sędziego w świetle etyki fenomenologicznej, [w:] W. Staśkiewicz, T. Stawecki, Dyskrecjonalność..., s. 257. 
słusznego rozstrzygnięcia. Mimo że sędzia stara się orzekać niezawiśle, podejmować decyzje w sposób wolny od jakichkolwiek bezpośrednich lub pośrednich nacisków zewnętrznych oraz bezstronnie, tj. niezależnie od ocen wynikających z osobistego doświadczenia ${ }^{22}$, stereotypów, poglądów czy uprzedzeńn ${ }^{23}$, to - w ocenie autorek - nie uniknie tego psychologicznego, może często nieuświadamianego aspektu.

W trakcie orzekania sędziowie ujawniają nie tylko zachowania typowe dla ich profesji i obowiązujących procedur sądowych, lecz także, tak jak każdy człowiek, przejawiają indywidualne cechy osobowości. Poza tym, podejmując decyzję w sytuacji określonej przez rzeczywistość sali rozpraw (otoczenie bliskie), a jednocześnie ukierunkowanej społecznie (otoczenie dalsze), mogą ulegać symptomowi presji społecznej ${ }^{24}$. Zwłaszcza, że podejmując decyzje i wydając oceny, doświadczają często sytuacji trudnej. W takiej sytuacji podleganie prawom psychologicznym, charakterystycznym dla procesów podejmowania decyzji, może być jeszcze większe. Wiele oczywiście zależy od indywidualnych cech jednostki - decydenta. Temperament, odporność na stres, poziom asertywności, inteligencja, a także różne doświadczenia osobiste, rodzinne i zawodowe, przyjęty przez sędziego system wartości i wyznawane poglądy będą nadawały decyzji sędziowskiej indywidualny (osobowy) charakter. Stąd decyzja podjęta w analogicznej sytuacji faktycznej, ale przez sędziów o różnych osobowościach może być odmienna ${ }^{25}$.

Należy zauważyć, że nawet tam, gdzie przepisy prawa nie pozostawiają sędziemu żadnego luzu decyzyjnego, pojawia się indywidualny psychologiczny proces podejmowania decyzji ${ }^{26}$. Sędzia może przecież podjąć decyzje cząstkowe, które ostatecznie nie doprowadzą do orzeczenia konkretnych konsekwencji ${ }^{27}$.

Proces podejmowania decyzji będzie jeszcze bardziej złożony, kiedy decyzja podejmowana jest przez sąd w składzie wieloosobowym. W czasie pracy zespołowej zachodzić mogą bowiem pewne deformacje myślenia, określane jako syndrom myślenia grupowego. Ciekawy poznawczo może być mechanizm nakładania się na siebie wypadkowych ocen poszczególnych sędziów i całego składu orzekającego.

\footnotetext{
${ }^{22} \mathrm{~Np}$. w sytuacji, kiedy sędzia ma wydać wyrok w stosunku do oskarżonego o kradzież samochodu, podczas gdy temu sędziemu skradziono wcześniej samochód.

${ }^{23}$ Por. wyrok Trybunału Konstytucyjnego z 9 listopada 1993 r., K 11/93, OTK 1993, nr 2, poz. 37.

${ }^{24}$ Por. T. Tyszka, op. cit., s. 51-64.

${ }^{25}$ Potwierdzają to badania przeprowadzone na sędziach amerykańskich, a przytoczone przez T. Tyszkę w pracy Psychologiczne pułapki oceniania i podejmowania decyzji - zob. T. Tyszka, op. cit., s. 21.

${ }^{26}$ Według T. Tyszki „w każdym przypadku orzeczniczego stosowania prawa mamy do czynienia z procesem psychicznym - tworzeniem ocen" - zob. T. Tyszka, op. cit., s. 13.

${ }^{27}$ Zwracał na to uwagę już J. Wróblewski, op. cit., s. 245.
} 
5. Nie ulega wątpliwości, że właściwości sędziego wpływają na treść decyzji. Powszechnie uznaje się, że sędzia, stosując prawo, posługuje się ocenami. Wydaje się zatem, iż znajomość procesów psychicznych, podlegających określonym prawom, ale też i zniekształceniom, wywierającym w mniejszym lub większym stopniu wpływ na treść wydanego rozstrzygnięcia, jest istotna z punktu widzenia prawidłowości podejmowanych decyzji i optymalizacji procesu decyzyjnego ${ }^{28}$.

Uzasadnione jest podjęcie badań nad psychologią stosowania prawa ${ }^{29}$. Nadal bowiem psychologiczna analiza podejmowania decyzji przez sędziów oparta jest przede wszystkim na dorobku ogólnych teorii podejmowania decyzji oraz psychologii (poznawczej i społecznej), a nie na badaniach psychologicznych osób sprawujących urząd sędziego.

Nasuwają się pytania o skalę zniekształceń wynikających z psychologicznego zaangażowania sędziego, sądowego procesu decyzyjnego i czynników zaburzających obiektywną ocenę prawną. W jakim stopniu, w przypadku sędziów, mamy do czynienia z tzw. efektem pierwszego wrażenia, polegającym na przecenieniu pierwszych informacji i dowodów, albo efektem świeżości, charakteryzującym się znacznym wyolbrzymieniem ostatnio przedstawionych dowodów, czy efektem aureoli, który jest skłonnością do przenoszenia określonych ocen z jednych sytuacji na inne? Kiedy pozytywna ocena pewnych zachowań oskarżonego może łagodzić ocenę innych jego zachowań relewantnych dla rozstrzygnięcia sprawy? Interesujące może być też pytanie o skalę występowania tzw. błędu tendencji centralnej, tj. pytanie o to, jak często sędziowie rezygnuja z odważnych ocen na rzecz bardziej ostrożnych i zachowawczych, np. zgodnych z linią orzeczniczą sądu wyższej instancji ${ }^{30}$. Wydaje się, że na wszystkie te pytania można udzielić odpowiedzi i wskazać dyspozycję sędziego do określonego oceniania, zauważyć pewne tendencje oceniające i ustalić, czy istnieje, a jeśli tak, to jaki jest stopień jednolitości jego ocen, a następnie wskazać oceny, które sędzia preferuje przy podejmowaniu określonych decyzji.

Interesujące może być wyjaśnienie, z jakich powodów sędzia podjął konkretną decyzję, czy to finalną, czy cząstkową. I nie chodzi tu o szukanie przesłanek logicznych. Tam, gdzie pojawia się dyskrecjonalność sędziowska i pewna doza elastyczności, wchodzi też w grę psychologia podejmowania decyzji. Znacząca jest bowiem rola ocen i postaw sądu w podejmowaniu decyzji.

Obszary zainteresowań i możliwe pola badań mogą też obejmować zagadnienia wpływu stanu emocjonalnego, nastroju sędziego na sposób decydowania, jego odporność na presję ze strony najbliższego otoczenia związanego z sytuacją na sali rozpraw i ze strony otoczenia dalszego.

\footnotetext{
${ }^{28}$ Por. T. Tyszka, op. cit., s. 13.

${ }^{29}$ Zauważał to już J. Wróblewski, op. cit., s. 24.

${ }^{30}$ Por. T. Tyszka, op. cit., s. 24-26.
} 